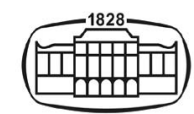

AKADÉMIAI KIADÓ

Acta Microbiologica et Immunologica Hungarica

67 (2020) 1, 33-41

DOI: $10.1556 / 030.66 .2019 .042$

(c) 2019 Akadémiai Kiadó, Budapest

ORIGINAL ARTICLE

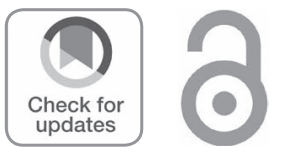

\section{Coexistence of genes encoding aminoglycoside modifying enzymes among clinical Acinetobacter baumannii isolates in Ahvaz, Southwest Iran}

\author{
FARKHONDEH SALEH SHOOSHTARI ${ }^{1,2}$, \\ TAHEREH NAVIDIFAR ${ }^{1} *$ MANSOUR AMIN ${ }^{1,3}$ and \\ HAMED GOODARZI ${ }^{1}$
}

\author{
${ }^{1}$ Department of Microbiology, School of Medicine, Ahvaz Jundishapur University of Medical Sciences, \\ Ahvaz, Iran \\ ${ }^{2}$ Infertility Research and Treatment Center of Jahad Daneshgahi, Ahvaz, Iran \\ ${ }^{3}$ Infectious and Tropical Diseases Research Center, Health Research Institute, Ahvaz Jundishapur \\ University of Medical Sciences, Ahvaz, Iran
}

Received: September 02, 2019 • Accepted: October 16, 2019 • Published online: December 13, 2019

\begin{abstract}
Aminoglycosides are widely recommended for treatment of Acinetobacter baumannii infections in combination with $\beta$-lactams or quinolones. This cross-sectional study was aimed to investigate the coexistence of aminoglycoside modifying enzyme (AME) genes among A. baumannii isolates from clinical samples in Ahvaz, Iran. A total of 85 clinical A. baumannii isolates typed by ERIC-PCR were investigated for the presence of AME genes, including $\operatorname{ant}\left(3^{\prime \prime}\right)-I a, a a c\left(6^{\prime}\right)-I b, \operatorname{aac}\left(3^{\prime}\right)-I a$, $\operatorname{ant}\left(2^{\prime \prime}\right)-I a$, and $a p h\left(3^{\prime}\right)$-VIa by PCR. The resistance rates to aminoglycoside agents were evaluated by disk diffusion. In this study, 84 out of $85 \mathrm{~A}$. baumannii isolates were resistant to at least one of the aminoglycosides and harbored at least one AME gene. The most common gene encoding AMEs was aph ( $\left.3^{\prime}\right) V I a$, followed by $a a c\left(3^{\prime}\right)-I a$, ant $\left(3^{\prime \prime}\right)-I a$, ant $\left(2^{\prime \prime}\right)-I a$, and $a a c\left(6^{\prime}\right)-I b$. The aminoglycoside-resistant genotypes were completely matched to resistant phenotypes to each one of the aminoglycoside agents. There was a clear association between AME gene types and the phenotype of resistance to aminoglycosides with their ERIC-PCR types. Our findings highlight the coexistence of AME genes and clonal dissemination of multiresistant A. baumannii in hospital setting.
\end{abstract}

\section{KEYWORDS}

aminoglycoside, aminoglycoside modifying enzymes, Acinetobacter baumannii

\section{INTRODUCTION}

Acinetobacter baumannii is a common nosocomial opportunistic pathogen that can cause severe infections including pneumonia, meningitis, bacteremia, urinary tract infections, surgical wounds, as well as soft tissue infections [1]. In the past two decades, according to some reports, the relatively high prevalence of this microorganism has been reported, especially from intensive care units where patients are treated with broad-spectrum antimicrobial agents [2]. The extensive use of antibiotics in hospitals has been associated with the increasing emergence and dissemination of multidrug-resistant (MDR) A. baumannii isolates [3].

Moreover, A. baumannii is resistant to most commonly used antibiotics, including aminoglycosides [4]. Aminoglycosides are widely recommended in combination with $\beta$-lactams or quinolones for the treatment of infections caused by Gram-negative bacilli, such as A. baumannii. Despite side effects and increasing resistance of A. baumannii isolates to

\footnotetext{
* Corresponding author: Tahereh Navidifar Department of Microbiology, School Medicine, Ahvaz Jundishapur Universt Ahvaz 6194863377, Iran P 9807292597 
aminoglycoside agents, they yet retain as the valuable therapeutic choices because of their bactericidal activity and their synergy with $\beta$-lactams [5]. The most common mechanism of resistance to aminoglycosides in A. baumannii strains is enzymatic modifications. Moreover, aminoglycoside modifying enzymes (AMEs) catalyze the modification at $-\mathrm{OH}$ or $-\mathrm{NH} 2$ groups of the 2-deoxystreptamine nucleus or the sugar moieties and thereby can be acetyltransferases, nucleotidyltranferases, or phosphotransferases. These genes encoding AMEs can be transferred at the molecular level as part of gene cassettes harbored on integrons and at the cellular level through conjugation [6]. Other mechanisms conferring resistance to aminoglycosides are efflux pumps, 16s RNA methylases, substitution of ribosomal proteins, and mutation of 16S rRNA [7].

Previous studies in Iran indicated a relatively high prevalence of AME genes among A. baumannii strains [8-11]. However, already, the distribution of these genes is not evaluated in our region, Ahvaz, Iran; hence, in this present work, we investigated the distribution of genes encoding AMEs among A. baumannii strains from clinical samples of hospitalized patients in two teaching hospitals in Ahvaz, Iran.

\section{MATERIALS AND METHODS}

\section{Study design and bacterial isolates}

This cross-sectional study was performed on 85 nonduplicate clinical A. baumannii isolates. These isolates were obtained from our previous study on different clinical specimens (including blood, urine, trachea, and wound) of hospitalized patients in Taleghani and Imam Khomeini Hospitals in Ahvaz, Iran. The phenotypic identification of these isolates was performed using biochemical tests in our previous study [12]. In addition, the molecular identification of $A$. baumannii isolates was performed by the amplification of $b l a_{\text {OXA-51-like }}$ gene using the previously described primers by Turton et al. [13]. The A. baumannii ATCC19606 was used as the reference strain.

\section{Antibiotic susceptibility testing}

The antibiotic susceptibility of these isolates was determined by disk diffusion method according to the Clinical and Laboratory Standards Institute guidelines [14] in our previous study [12]. In addition, in this study, antibiotic susceptibility to tobramycin was evaluated by disk diffusion method. Briefly, the bacterial suspensions were prepared by suspending isolated colonies from fresh overnight culture plates in sterile normal saline and adjusted to a $0.5 \mathrm{McFar}-$ land standard. The following antibiotic impregnated disks were used: imipenem $(10 \mu \mathrm{g})$, meropenem $(10 \mu \mathrm{g})$, ceftazidime $(30 \mu \mathrm{g})$, cefotaxime $(30 \mu \mathrm{g})$, ciprofloxacin $(5 \mu \mathrm{g})$, gentamicin $(10 \mu \mathrm{g})$, amikacin $(30 \mu \mathrm{g})$, tetracycline $(30 \mu \mathrm{g})$, piperacillin $(100 \mu \mathrm{g})$, cefepime $(30 \mu \mathrm{g})$, piperacillin/ tazobactam $(100 / 10 \mu \mathrm{g})$, trimethoprim/sulfamethoxazole
$(1.25 / 23.75 \mu \mathrm{g})$, colistin $(10 \mu \mathrm{g})$, ampicillin/sulbactam $(10 / 10 \mu \mathrm{g})$, tobramycin $(10 \mu \mathrm{g})$, ceftriaxone $(30 \mu \mathrm{g})$, and polymyxin B (300 U). Then, the plates were incubated at $37^{\circ} \mathrm{C}$ for $18-24 \mathrm{~h}$, and the diameters of the inhibition zones were measured in millimeters.

\section{DNA extraction}

Total DNA extraction was performed using boiling method. Briefly, the colonies suspected to be A. baumannii were suspended in $500 \mu \mathrm{l}$ of TE buffer $(10 \mathrm{mM}$ Tris- $\mathrm{HCl}$ and $0.1 \mathrm{mM}$ EDTA, $\mathrm{pH} 8.0$ ), boiled at $95{ }^{\circ} \mathrm{C}$ for $10 \mathrm{~min}$, and centrifuged at $14,000 \times g$ for $5 \mathrm{~min}$. The supernatants were collected as DNA templates and were stored at $-20{ }^{\circ} \mathrm{C}$ for the polymerase chain reaction (PCR) assay [15].

\section{Enterobacterial repetitive intergenic consensus (ERIC)-PCR typing}

Genetic relatedness of $A$. baumannii isolates was evaluated in our previous study [12] using the ERIC-PCR with primers ERIC-F (5'-ATGTAAGCTCCTGGGGATTCAC-3') and ERIC-R (5'-AAGTAAGTGACTGGGGTGA GCG-3') [16]. Briefly, the PCR reaction was performed in the final volume of $25 \mu \mathrm{l}$ containing $1 \mathrm{U}$ Taq DNA polymerase, $1.5 \mathrm{mM}$ of $\mathrm{MgCl}_{2}, 200 \mu \mathrm{M}$ of dNTPs, $0.5 \mu \mathrm{M}$ of each primer, $10 \times$ PCR buffer, $6.5 \mu$ l of template DNA, and distilled water up to a final volume of $25 \mu$ l. The amplification process was performed in Mastercycler Nexus Thermal Cycler Gradient (Eppendorf, Hamburg, Germany) with one cycle of initial denaturation at $94{ }^{\circ} \mathrm{C}$ for $5 \mathrm{~min}$, followed by 35 cycles of denaturation at $94{ }^{\circ} \mathrm{C}$ for $60 \mathrm{~s}$, annealing at $57^{\circ} \mathrm{C}$ for $60 \mathrm{~s}$, extension at $72{ }^{\circ} \mathrm{C}$ for $80 \mathrm{~s}$, and a cycle of final extension at $72{ }^{\circ} \mathrm{C}$ for $10 \mathrm{~min}$. The amplified products were visualized on $1.5 \%$ agarose gel, stained with safe stain. The data analyses were performed using the Gel Compare II software version 6.6 (Applied Math, Sint-Martens-Latem, Belgium). The similarity pattern was calculated using the unweighted-pair group method/the Dice similarity coefficient with a position tolerance of $1 \%$. Isolates with more than $90 \%$ similarity were considered as a clonal type.

\section{Amplification of AME genes by PCR}

All isolates without respect to their resistance levels to aminoglycoside agents were subjected to the detection of the genes encoding AMEs $\left[a a c\left(6^{\prime}\right)-I b+a a c\left(3^{\prime}\right)-I a+a n t\left(2^{\prime \prime}\right)-I a\right.$, ant $\left.\left(3^{\prime \prime}\right)-I a+a p h\left(3^{\prime}\right)-V I a\right]$ using the specific primers listed in Table I $[9,17]$. The amplification reactions were prepared in a final volume of $20 \mu \mathrm{l}$ containing $1 \mathrm{U}$ of Taq DNA polymerase, $1.5 \mathrm{mM} \mathrm{MgCl}_{2}, 200 \mu \mathrm{M}$ dNTPs, $0.4 \mu \mathrm{M}$ of each primer (forward and reverse), 10× PCR buffer, $1.5 \mu \mathrm{l}$ of template DNA (100 pg concentration) and nuclease free water up to a final $20 \mu \mathrm{l}$. The amplification reactions were performed in a thermocycler (Applied Biosystems, USA) with one cycle initial denaturation at $95{ }^{\circ} \mathrm{C}$ for $3 \mathrm{~min}, 35$ cycles with a denaturation temperature of $95{ }^{\circ} \mathrm{C}$ for $45 \mathrm{~s}$, 
Table I. Primer sets used in this study

\begin{tabular}{|c|c|c|c|c|}
\hline Gene & Primer $\left(5^{\prime}-3^{\prime}\right)$ & Amplicon size (bp) & $\begin{array}{c}\text { Annealing } \\
\text { temperature }\left({ }^{\circ} \mathrm{C}\right)\end{array}$ & Ref. \\
\hline $\operatorname{Aph}\left(3^{\prime}\right)-\mathrm{F}$ & ATGGAATTGCCCAATATTATTC & \multirow[t]{2}{*}{797} & \multirow[t]{2}{*}{55} & \multirow[t]{2}{*}{ [9] } \\
\hline $\operatorname{aph} A\left(3^{\prime}\right)-\mathrm{R}$ & TCAАTTCAАTTСАTCAAGTTTTA & & & \\
\hline $\operatorname{ant}\left(3^{\prime \prime}\right)-\mathrm{F}$ & ATGAGGGAAGCGGTGATCG & \multirow[t]{2}{*}{792} & \multirow[t]{2}{*}{52} & \multirow[t]{2}{*}{ [9] } \\
\hline $\operatorname{ant}\left(3^{\prime \prime}\right)-\mathrm{R}$ & TIATTTGCCGACTACCTTGGTG & & & \\
\hline $\operatorname{ant}\left(2^{\prime \prime}\right)-\mathrm{F}$ & ATGGACACAACGCAGGTCGC & \multirow[t]{2}{*}{534} & \multirow[t]{2}{*}{55} & \multirow[t]{2}{*}{ [9] } \\
\hline $\operatorname{ant}\left(2^{\prime \prime}\right)-\mathrm{R}$ & TTAGGCCGCATATCGCGACC & & & \\
\hline $\operatorname{aac}\left(3^{\prime}\right)-l a-F$ & ATGGGCATCATTCGCACATGTAGG & \multirow[t]{2}{*}{456} & \multirow[t]{2}{*}{52} & \multirow[t]{2}{*}{ [9] } \\
\hline $\operatorname{aac}\left(3^{\prime}\right)-\operatorname{la}-\mathrm{R}$ & TIAGGTGGCGGTACTTGGGTC & & & \\
\hline $\operatorname{aac}\left(6^{\prime}\right)-1 b$ & ATGACTGAGCATGACCTTG & \multirow[t]{2}{*}{524} & \multirow[t]{2}{*}{52} & \multirow[t]{2}{*}{ [17] } \\
\hline $\operatorname{aac}\left(6^{\prime}\right)-I b$ & AAG GGT TAG GCA ACA CTG & & & \\
\hline
\end{tabular}

annealing temperature of $52^{\circ} \mathrm{C}$ for $\operatorname{ant}\left(3^{\prime \prime}\right)-I a, a a c\left(6^{\prime}\right)-I b$ and $a a c\left(3^{\prime}\right)-I a$ and $55^{\circ} \mathrm{C}$ for $\operatorname{ant}\left(2^{\prime \prime}\right)-I a$ and $a p h\left(3^{\prime}\right)-V I a$ for $45 \mathrm{~s}$, extension at $72{ }^{\circ} \mathrm{C}$ for $30 \mathrm{~s}$, and a final extension step at $72{ }^{\circ} \mathrm{C}$ for $5 \mathrm{~min}$. PCR products were electrophoresed on $1 \%$ agarose gel at $100 \mathrm{~V}$ for $60 \mathrm{~min}$ and were staining with safe stain.

\section{RESULTS}

\section{Determination of antibiotic susceptibility}

In this study, among $85 \mathrm{~A}$. baumannii isolates, resistance to amikacin, ceftazidime, ceftriaxone, cefepime, ciprofloxacin, cefotaxime, gentamicin, tobramycin, imipenem, meropenem, piperacillin/tazobactam, piperacillin, ampicillin/ sulbactam, trimethoprim/sulfamethoxazole, and tetracycline was seen in $76(89.41 \%), 76(89.41 \%), 77(90.58 \%)$, 76 (89.41\%), 76 (89.41\%), 77 (90.58\%), 78(91.8\%), 51 (60\%), $71 \quad(83.52 \%), \quad 74 \quad(87.05 \%), \quad 77 \quad(90.58 \%)$, $76(89.41 \%), 44(51.76 \%), 75(88.23 \%)$, and $49(57.64 \%)$ isolates, respectively. All strains were sensitive to polymyxin B and only two strains were resistant to colistin. Altogether 77 out of these 85 (90.58\%) A. baumannii isolates were identified as MDR, as reported in our previous study.

\section{ERIC-PCR analysis}

In this study, $85 \mathrm{~A}$. baumanni isolates were classified into 21 clone types (CT) and 23 single types (ST) of ERIC-PCR, as reported in our previous study [12]; among which CT16 with 6 isolates was as the most common clone type obtained from this analysis. Table II shows the resistance to aminoglycoside agents, including gentamicin, amikacin, and tobramycin among these isolates with respect to their ERIC-PCR types.
According to these results, there was a significant association $(p<0.05)$ between the clone types and the resistance to these aminoglycoside agents.

\section{Frequency rate of genes encoding AMEs}

In this study, 84 out of $85 \mathrm{~A}$. baumannii isolates were resistant to at least one of the aminoglycoside agents and these isolates harbored at least one of genes encoding AMEs. The most common gene encoding AMEs was aph (3')VIa (50 isolates, $58.82 \%$ ), followed by aac( $\left.3^{\prime}\right)-I a$ (45 isolates, $52.9 \%)$, ant (3")-Ia (38 isolates, $44.7 \%)$, ant (2")-Ia (28 isolates, $32.9 \%$ ), and $a a c\left(6^{\prime}\right)-I b$ (27 isolates, $\left.31.76 \%\right)$. According to our results, the coexistence of two or more than two gene encoding AMEs was found in $55(64.70 \%)$ isolates. The distribution patterns of genes encoding AMEs among $A$. baumannii isolates with respect to their substrates are shown in Table II. According to the data, we indicated 18 coexistence pattern of genes encoding AMEs, among which $a p h\left(3^{\prime}\right)-V I a+$ $\operatorname{aac}\left(3^{\prime}\right)$-Ia was the most common in the distribution pattern of genes encoding AMEs, followed by ant (3") $-I a+a a c\left(6^{\prime}\right)-I b+$

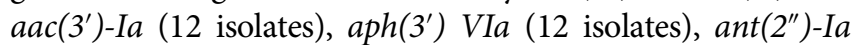
(7 isolates), ant ( $\left.2^{\prime \prime}\right)-I a+a p h\left(3^{\prime}\right)-V I a+a a c\left(3^{\prime}\right)-I a$ (7 isolates), and $a n t-\left(2^{\prime \prime}\right)-I a+a n t\left(3^{\prime \prime}\right)-I a+a a c\left(6^{\prime}\right)-I b$ (6 isolates).

\section{Association of between presence of AME genes and ERIC-PCR types}

Table III describes the pattern of genes encoding AMEs and the phenotype of resistance to aminoglycoside agents with respect to their ERIC-PCR types. According to our findings, there was a significant association $(p<0.05)$ between each one of genes encoding AMEs and the phenotype of resistance to aminoglycosides with their ERIC-PCR types. 
Table II. The distribution profile of AMEs among $A$. baumannii isolates with respect to their substrate

\begin{tabular}{|c|c|c|c|}
\hline Profile of AME genes & Substrate & Type & $N(\%)$ \\
\hline $\operatorname{ant}\left(2^{\prime \prime}\right)-l a+a p h\left(3^{\prime}\right)-V i a+a a c\left(3^{\prime}\right)-l a$ & G-A-T & СT01 and CT11 & $7(8.23)$ \\
\hline $\operatorname{ant}\left(3^{\prime \prime}\right)-l a+a a c\left(6^{\prime}\right)-l b+a a c\left(3^{\prime}\right)-l a$ & G-A-T & СТ02, СТ12, СТ13, and СТ14 & $12(14.11)$ \\
\hline $\operatorname{ant}\left(2^{\prime \prime}\right)-l a+a n t\left(3^{\prime \prime}\right) l a$ & G-T & ст03 & $2(2.35)$ \\
\hline $\operatorname{aph}\left(3^{\prime}\right)-V l a$ & $A-G$ & $\begin{array}{l}\text { СТ04, СТ08, СТ18, ST02, ST07, } \\
\text { ST21, ST22, and ST23 }\end{array}$ & $12(14.11)$ \\
\hline ant(3")-la & NOT & ST04 & $1(1.17)$ \\
\hline$a a c\left(6^{\prime}\right)-l b+a a c\left(3^{\prime}\right)-l a$ & G-A-T & СT05 and ST09 & $4(4.7)$ \\
\hline$a p h\left(3^{\prime}\right)-V i a+a a c(3)-l a$ & $A-G$ & $\begin{array}{l}\text { Ст06, Ст10, Sт05, ST06, ST16, } \\
\text { ST17, ST18, ST19, and ST20 }\end{array}$ & $13(15.29)$ \\
\hline $\operatorname{ant}\left(2^{\prime \prime}\right)-l a+a n t\left(3^{\prime \prime}\right)-l a+a a c\left(6^{\prime}\right)-l b$ & G-A-T & СТ07, СТ09, and ST08 & $6(7.05)$ \\
\hline $\operatorname{ant}\left(2^{\prime \prime}\right)-l a+a n t\left(3^{\prime \prime}\right)-l a+a a c\left(3^{\prime}\right)-l a$ & G-A & СТ19 & $3(3.52)$ \\
\hline $\operatorname{ant}\left(2^{\prime \prime}\right)-\operatorname{la}+a p h\left(3^{\prime}\right)-V i a$ & G-A-T & CT15 & $5(5.88)$ \\
\hline $\operatorname{aac}\left(3^{\prime}\right)-l a$ & G & ST10 & $1(1.17)$ \\
\hline$a n t\left(3^{\prime \prime}\right)-l a+a a c\left(6^{\prime}\right)-1 b$ & $A-T$ & CT16, & $5(5.88)$ \\
\hline $\operatorname{ant}\left(2^{\prime \prime}\right) l a+a n t\left(3^{\prime \prime}\right)-l a+a p h\left(3^{\prime}\right)-V l a$ & G-A-T & CT17 & $4(4.7)$ \\
\hline ant(2")-la & G-T & $\begin{array}{l}\text { CT20, ST01, ST11, ST12, ST13, } \\
\text { and ST15 }\end{array}$ & $7(8.23)$ \\
\hline $\operatorname{ant}\left(3^{\prime \prime}\right)-\operatorname{la}+a p h\left(3^{\prime}\right)-V l a$ & G-A & CT21 and ST14 & $3(3.52)$ \\
\hline $\operatorname{ant}\left(3^{\prime \prime}\right)-l a+a p h\left(3^{\prime}\right)-V l a+a a c\left(6^{\prime}\right)-I b$ & G-A-T & ST03 & $1(1.17)$ \\
\hline $\operatorname{ant}\left(3^{\prime}\right)-l a$ & NOT & ST04 & $1(1.17)$ \\
\hline $\operatorname{aac}\left(3^{\prime}\right)-l a$ & G & ST11 & $1(1.17)$ \\
\hline
\end{tabular}

Note: AME: aminoglycoside modifying enzyme; G: gentamicin; A: amikacin; T: tobramycin; F: forward; R: reverse.

\section{DISCUSSION}

Multidrug resistance in A. baumannii is a global challenge due to the lack of effective treatment options [18]. Aminoglycoside agents have been considered as one of the most important treatment options of infections caused by $A$. baumannii [19]. However, the antibiotic resistance rates to aminoglycoside agents are increasing among A. baumannii isolates that resulted in the reduction of the efficacy of these agents [20]. In this study, the rate of antibiotic resistance to tobramycin was lower than amikacin and gentamicin. Hence, it seems that tobramycin is the most effective aminoglycoside agent for the treatment of $A$. baumannii infections. In agreement with our results, several studies also confirmed the higher susceptibility of tobramycin rather than two other aminoglycoside agents in A. baumannii isolates [9, 21, 22].

In this study, we focused on the detection of genes encoding AMEs as the most common mechanism of resistance to aminoglycosides [6]. In addition, we indicated that all aminoglycoside-resistant isolates harbored at least one AME gene.

Moreover, the most common gene encoding AMEs was aph (3')VIa. Similar to our studies, there are many researches that have reported the distribution of genes encoding AMEs among A. baumannii [9, 22-24]. In addition, our findings are similar to the studies of Aghazadeh et al. [22] and Moniri et al. [20] who reported the aph (3')VIa gene as the most predominant gene encoding AMEs in the majority of aminoglycoside-resistant A. baumannii strains. However, some other researchers indicated the higher prevalence of other genes encoding AMEs rather than aph (3')VIa $[9,11$, 23-25]. These differences in the distribution patterns of AMEs may be due to the diversity in the dissemination of one or more clonal types in a region.

In this study, the association of each AME gene with resistance to a special aminoglycoside agent was not evaluated by statistical analysis because an A. baumannii strain may harbor simultaneously several genes encoding AMEs for 
Table III. Pattern of genes encoding AMEs and the phenotype of resistance to aminoglycoside agents with respect to their ERIC-PCR types

\begin{tabular}{|c|c|c|c|c|c|}
\hline Strain & Type & $\mathbf{G}$ & A & $\mathbf{T}$ & Genes \\
\hline SF01 & ST01 & $\mathrm{s}$ & $\mathbf{R}$ & $\mathrm{R}$ & ant( $\left(3^{\prime \prime}\right)-l a$ and $a p h\left(3^{\prime}\right)-V l a$ \\
\hline SF02 & ст01 & $\mathbf{R}$ & $\mathbf{R}$ & $\mathbf{R}$ & $\operatorname{ant}\left(2^{\prime \prime}\right)-l a, \operatorname{aph}\left(3^{\prime \prime}\right)-V I a$, and $\operatorname{aac}\left(3^{\prime}\right)-l a$ \\
\hline SF03 & ст01 & $\mathbf{R}$ & $\mathbf{R}$ & $\mathbf{R}$ & $\operatorname{ant}\left(2^{\prime \prime}\right)-l a, \operatorname{aph}\left(3^{\prime}\right)-V l a$, and $\operatorname{aac}\left(3^{\prime}\right)-l a$ \\
\hline SF04 & ST02 & $\mathbf{R}$ & $\mathbf{R}$ & $\mathrm{S}$ & $\operatorname{aph}\left(3^{\prime}\right)-$ Vla \\
\hline SF05 & ST03 & $\mathbf{R}$ & $\mathbf{R}$ & $\mathrm{R}$ & ant((3")-la, aph(3)-Vla, and aac(6)-Ib \\
\hline SF06 & Ст02 & $\mathrm{R}$ & $\mathbf{R}$ & $\mathrm{R}$ & $\operatorname{ant}\left(3^{\prime \prime}\right)-l a, \operatorname{aac}(3)-l a$, and $\operatorname{aac}(6)--1 b$ \\
\hline SF07 & ст02 & $\mathbf{R}$ & $\mathbf{R}$ & $\mathbf{R}$ & ant((3")-la, aac(3)-la, and $\operatorname{aac}(6)-I b$ \\
\hline SF08 & ст02 & $\mathrm{R}$ & $\mathbf{R}$ & $\mathrm{R}$ & ant(3")-la, aac(3)-la, and $\operatorname{aac}(6)-1 b$ \\
\hline SF09 & ST04 & $\mathrm{S}$ & $\mathrm{s}$ & $\mathrm{S}$ & ant(3")-la \\
\hline SF10 & ст03 & $\mathbf{R}$ & $\mathrm{S}$ & $\mathbf{R}$ & ant(2)-la and ant( $\left.3^{\prime \prime}\right)-l a$ \\
\hline SF11 & ст03 & $\mathbf{R}$ & $\mathrm{S}$ & $\mathbf{R}$ & ant(2)-la and ant(3")-la \\
\hline SF12 & ST05 & $\mathbf{R}$ & $\mathbf{R}$ & $S$ & aph(3)-Vla, and aac(3)-la \\
\hline SF13 & ST06 & $\mathrm{R}$ & $\mathbf{R}$ & $\mathrm{S}$ & aph(3)-Vla, and aac(3)-la \\
\hline SF14 & ст04 & $\mathbf{R}$ & $\mathbf{R}$ & $\mathrm{S}$ & aph(3)-Vla \\
\hline SF15 & Ст04 & $\mathbf{R}$ & $\mathbf{R}$ & $\mathrm{S}$ & aph(3)-Vla \\
\hline SF16 & Ст05 & $\mathrm{R}$ & $\mathrm{R}$ & $\mathrm{R}$ & $a a c(3)-l a$ and $a a c(6)-I b$ \\
\hline SF17 & Ст05 & $\mathbf{R}$ & $\mathbf{R}$ & $\mathbf{R}$ & $a a c(3)-l a$ and $a a c(6)-I b$ \\
\hline SF18 & Ст05 & $\mathbf{R}$ & $\mathrm{R}$ & $\mathbf{R}$ & $a a c(3)-l a$ and $a a c(6)-l b$ \\
\hline SF19 & Ст06 & $\mathrm{R}$ & $\mathrm{R}$ & $\mathrm{S}$ & aph(3)-Vla and aac(3)-la \\
\hline SF20 & ст06 & $\mathbf{R}$ & $\mathbf{R}$ & $\mathrm{S}$ & aph(3)-Vla and aac(3)-la \\
\hline SF21 & ст06 & $\mathbf{R}$ & $\mathbf{R}$ & $S$ & aph(3)-Vla and aac(3)-la \\
\hline SF22 & СТ07 & $\mathrm{R}$ & $\mathrm{R}$ & $\mathrm{R}$ & ant(2)-la, ant((3")-la, and aac(6)-Ib \\
\hline SF23 & СТ07 & $\mathbf{R}$ & $\mathbf{R}$ & $\mathbf{R}$ & $\operatorname{ant}\left(2^{\prime \prime}\right)-l a, \operatorname{ant}\left(3^{\prime \prime}\right)-l a$, and $\operatorname{aac}(6)-I b$ \\
\hline SF24 & Ст08 & $\mathrm{R}$ & $\mathrm{R}$ & $\mathrm{S}$ & $\operatorname{aph}\left(3^{\prime}\right)-$ Vla \\
\hline SF25 & ст08 & $\mathrm{R}$ & $\mathbf{R}$ & $\mathrm{S}$ & $\operatorname{aph}\left(3^{\prime}\right)-$ Vla \\
\hline SF26 & ST07 & $\mathbf{R}$ & $\mathbf{R}$ & $\mathrm{S}$ & $\operatorname{aph}\left(3^{\prime}\right)-$ Vla \\
\hline SF27 & Ст09 & $\mathbf{R}$ & $\mathbf{R}$ & $\mathrm{R}$ & $\operatorname{ant}\left(3^{\prime \prime}\right)-l a$, ant $\left(2^{\prime \prime}\right)-l a$, and $\operatorname{aac}\left(6^{\prime}\right)-1 b$ \\
\hline SF28 & Ст09 & $\mathbf{R}$ & $\mathbf{R}$ & $\mathbf{R}$ & $\operatorname{ant}\left(3^{\prime \prime}\right)-l a, \operatorname{ant}\left(2^{\prime \prime}\right)-l a$, and $\operatorname{aac}\left(6^{\prime}\right)-1 b$ \\
\hline SF29 & ST08 & $\mathbf{R}$ & $\mathbf{R}$ & $\mathbf{R}$ & $\operatorname{ant}\left(3^{\prime \prime}\right)-l a$, ant $\left(2^{\prime \prime}\right)-l a$, and $\operatorname{aac}\left(6^{\prime}\right)-l b$ \\
\hline $\mathrm{SF} 30$ & ST09 & $\mathrm{R}$ & $\mathbf{R}$ & $\mathrm{R}$ & $\operatorname{aac}\left(3^{\prime}\right)-l a$ and $\operatorname{aac}\left(6^{\prime}\right) I-b$ \\
\hline SF31 & СT10 & $\mathbf{R}$ & $\mathbf{R}$ & $\mathrm{S}$ & $a p h\left(3^{\prime}\right)-V l a$ and $\operatorname{aac}\left(3^{\prime}\right)-l a$ \\
\hline SF32 & СТ10 & $\mathbf{R}$ & $\mathbf{R}$ & $\mathrm{S}$ & $a p h\left(3^{\prime}\right)-V l a$ and $\operatorname{aac}\left(3^{\prime}\right)-l a$ \\
\hline SF33 & ST10 & $\mathbf{R}$ & $\mathbf{R}$ & $\mathrm{S}$ & $a p h\left(3^{\prime}\right)-V l a$ and $a a c\left(3^{\prime}\right)-l a$ \\
\hline
\end{tabular}


Table III. Pattern of genes encoding AMEs and the phenotype of resistance to aminoglycoside agents with respect to their ERIC-PCR types (Continued)

\begin{tabular}{|c|c|c|c|c|c|}
\hline Strain & Type & G & A & $\mathbf{T}$ & Genes \\
\hline SF34 & ST11 & $\mathbf{R}$ & $S$ & S & $\operatorname{aac}\left(3^{\prime}\right)-l a$ \\
\hline SF35 & ST12 & $\mathbf{R}$ & S & $\mathbf{R}$ & ant(2")-la \\
\hline SF36 & CT11 & $\mathbf{R}$ & $\mathbf{R}$ & $\mathbf{R}$ & $\operatorname{ant}\left(2^{\prime \prime}\right)-l a$, aph$\left(3^{\prime}\right)-V l a$, and $\operatorname{aac}\left(3^{\prime}\right)-l a$ \\
\hline SF37 & CT11 & $\mathbf{R}$ & $\mathbf{R}$ & $\mathbf{R}$ & $\operatorname{ant}\left(2^{\prime \prime}\right)-l a, a p h\left(3^{\prime}\right)-V l a$, and $\operatorname{aac}\left(3^{\prime}\right)-l a$ \\
\hline SF38 & CT11 & $\mathrm{R}$ & $\mathbf{R}$ & R & $\operatorname{ant}\left(2^{\prime \prime}\right)-l a, \operatorname{aph}\left(3^{\prime}\right)-V l a$, and $\operatorname{aac}(3)-l a$ \\
\hline SF39 & CT11 & $\mathbf{R}$ & $\mathbf{R}$ & $\mathbf{R}$ & $\operatorname{ant}\left(2^{\prime \prime}\right)-l a, a p h\left(3^{\prime}\right)-V l a$, and $\operatorname{aac}\left(3^{\prime}\right)-l a$ \\
\hline SF40 & CT11 & $\mathbf{R}$ & $\mathbf{R}$ & $\mathbf{R}$ & 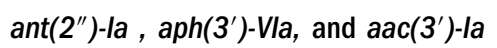 \\
\hline SF41 & CT12 & $\mathrm{R}$ & $\mathbf{R}$ & $\mathrm{R}$ & $\operatorname{aac}\left(3^{\prime}\right)-l a, \operatorname{aac}\left(6^{\prime}\right)-1 b$, and ant $\left(3^{\prime \prime}\right)-l a$ \\
\hline SF42 & СT12 & $\mathbf{R}$ & $\mathbf{R}$ & $\mathbf{R}$ & $\operatorname{aac}\left(3^{\prime}\right)-l a, \operatorname{aac}\left(6^{\prime}\right)-1 b$, and $\operatorname{ant}\left(3^{\prime \prime}\right)-l a$ \\
\hline SF43 & СT13 & $\mathbf{R}$ & $\mathbf{R}$ & $\mathbf{R}$ & $\operatorname{aac}\left(3^{\prime}\right)-l a, \operatorname{aac}\left(6^{\prime}\right)-1 b$, and ant( $\left(3^{\prime \prime}\right)-l a$ \\
\hline SF44 & CT13 & $\mathrm{R}$ & $\mathbf{R}$ & $\mathrm{R}$ & $\operatorname{aac}\left(3^{\prime}\right)-l a, \operatorname{aac}\left(6^{\prime}\right)-1 b$, and $\operatorname{ant}\left(3^{\prime \prime}\right)-l a$ \\
\hline SF45 & CT14 & $\mathbf{R}$ & $\mathrm{R}$ & $\mathbf{R}$ & $\operatorname{aac}\left(3^{\prime}\right)-l a, \operatorname{aac}\left(6^{\prime}\right)-l b$, and $\operatorname{ant}\left(3^{\prime \prime}\right)-l a$ \\
\hline SF46 & CT14 & $\mathbf{R}$ & $\mathbf{R}$ & $\mathbf{R}$ & $\operatorname{aac}\left(3^{\prime}\right)-l a, \operatorname{aac}\left(6^{\prime}\right)-1 b$, and ant $\left(3^{\prime \prime}\right)-l a$ \\
\hline SF47 & CT14 & $\mathrm{R}$ & $\mathbf{R}$ & $\mathrm{R}$ & $\operatorname{aac}\left(3^{\prime}\right)-l a, \operatorname{aac}\left(6^{\prime}\right)-l b$, and $\operatorname{ant}\left(3^{\prime \prime}\right)-l a$ \\
\hline SF48 & CT14 & $\mathrm{R}$ & $\mathbf{R}$ & $\mathbf{R}$ & $\operatorname{aac}\left(3^{\prime}\right)-l a, \operatorname{aac}\left(6^{\prime}\right)-l b$, and $a n t\left(3^{\prime \prime}\right)-l a$ \\
\hline SF49 & CT14 & $\mathbf{R}$ & $\mathbf{R}$ & $\mathbf{R}$ & $\operatorname{aac}\left(3^{\prime}\right)-l a, \operatorname{aac}\left(6^{\prime}\right)-1 b$, and ant( $\left(3^{\prime \prime}\right)-l a$ \\
\hline SF50 & ST13 & $\mathrm{R}$ & $\mathrm{R}$ & $\mathrm{R}$ & ant(2")-la \\
\hline SF51 & ST14 & $\mathbf{R}$ & $\mathbf{R}$ & $\mathrm{s}$ & 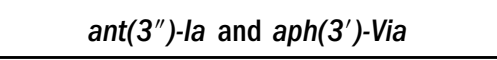 \\
\hline SF52 & ST15 & $\mathrm{R}$ & $\mathrm{S}$ & $\mathbf{R}$ & ant(2")-la \\
\hline SF53 & CT15 & $\mathbf{R}$ & $\mathbf{R}$ & $\mathrm{R}$ & ant(2")-la and aph(3')-Vla \\
\hline SF54 & CT15 & $\mathrm{R}$ & $\mathbf{R}$ & $\mathbf{R}$ & ant(2")-la and aph(3')-Vla \\
\hline SF55 & CT15 & $\mathrm{R}$ & $\mathrm{R}$ & $\mathbf{R}$ & ant( $\left(2^{\prime \prime}\right)-l a$ and $a p h\left(3^{\prime}\right)-V l a$ \\
\hline SF56 & CT15 & $\mathrm{R}$ & $\mathbf{R}$ & $\mathbf{R}$ & ant(2")-la and aph(3')-Vla \\
\hline SF57 & CT16 & $\mathrm{R}$ & $\mathrm{R}$ & $\mathrm{R}$ & ant $\left(2^{\prime \prime}\right)-l a$ and $a p h\left(3^{\prime}\right)-$ Vla \\
\hline SF58 & CT16 & $\mathrm{S}$ & $\mathbf{R}$ & $\mathbf{R}$ & ant(3") $)-l a$ and $\operatorname{aac}\left(6^{\prime}\right)-I b$ \\
\hline SF59 & CT16 & $\mathrm{S}$ & $\mathbf{R}$ & $\mathbf{R}$ & ant((3")-la and $\operatorname{aac}\left(6^{\prime}\right)-I b$ \\
\hline SF60 & CT16 & $\mathrm{s}$ & $\mathrm{R}$ & $\mathrm{R}$ & ant((3")-la and $\operatorname{aac}\left(6^{\prime}\right)-1 b$ \\
\hline SF61 & CT16 & $\mathrm{s}$ & $\mathbf{R}$ & $\mathrm{R}$ & ant $\left(3^{\prime \prime}\right)-l a$ and $\operatorname{aac}\left(6^{\prime}\right)-I b$ \\
\hline SF62 & CT16 & $\mathrm{s}$ & $\mathbf{R}$ & $\mathbf{R}$ & ant( $\left.3^{\prime \prime}\right)-l a$ and $\operatorname{aac}\left(6^{\prime}\right)-1 b$ \\
\hline SF63 & СТ17 & $\mathrm{R}$ & $\mathrm{R}$ & $\mathbf{R}$ & $\begin{array}{c}\operatorname{ant}\left(2^{\prime \prime}\right)-l a, \operatorname{aph}\left(3^{\prime}\right)-V l a, \text { ant }\left(3^{\prime \prime}\right)-l a, \text { and } \\
\operatorname{aac}\left(3^{\prime}\right)-l a\end{array}$ \\
\hline SF64 & СТ17 & $\mathbf{R}$ & $\mathbf{R}$ & $\mathbf{R}$ & 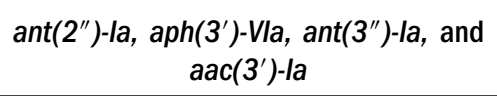 \\
\hline SF65 & CT17 & $\mathrm{R}$ & $\mathbf{R}$ & $\mathbf{R}$ & $\begin{array}{c}\operatorname{ant}\left(2^{\prime \prime}\right)-l a, \operatorname{aph}\left(3^{\prime}\right)-V l a, \operatorname{ant}\left(3^{\prime \prime}\right)-l a, \text { and } \\
\operatorname{aac}\left(3^{\prime}\right)-l a\end{array}$ \\
\hline
\end{tabular}


Table III. Pattern of genes encoding AMEs and the phenotype of resistance to aminoglycoside agents with respect to their ERIC-PCR types (Continued)

\begin{tabular}{|c|c|c|c|c|c|}
\hline Strain & Type & $\mathbf{G}$ & A & $\mathbf{T}$ & Genes \\
\hline SF66 & CT17 & $\mathbf{R}$ & $\mathbf{R}$ & $\mathbf{R}$ & $\begin{array}{c}\operatorname{ant}\left(2^{\prime \prime}\right)-l a, \operatorname{aph}\left(3^{\prime}\right)-V l a, \text { ant }\left(3^{\prime \prime}\right)-l a, \text { and } \\
\operatorname{aac}\left(3^{\prime}\right)-l a\end{array}$ \\
\hline SF67 & ST16 & $\mathbf{R}$ & $\mathbf{R}$ & $\mathrm{S}$ & aph $\left(3^{\prime}\right)-V l a$ and $a a c\left(3^{\prime}\right)-l a$ \\
\hline SF68 & CT18 & $\mathbf{R}$ & $\mathbf{R}$ & $\mathrm{S}$ & $\operatorname{aph}\left(3^{\prime}\right)-$ Vla \\
\hline SF69 & CT18 & $\mathbf{R}$ & $\mathbf{R}$ & $\mathrm{S}$ & $\operatorname{aph}\left(3^{\prime}\right)-$ Vla \\
\hline SF70 & CT18 & $\mathbf{R}$ & $\mathbf{R}$ & $\mathrm{S}$ & $\operatorname{aph}\left(3^{\prime}\right)-$ Vla \\
\hline SF71 & СT19 & $\mathbf{R}$ & $\mathbf{R}$ & $\mathrm{S}$ & $a p h\left(3^{\prime}\right)-V l a$, ant(3")-la, and $\operatorname{aac}\left(3^{\prime}\right)-l a$ \\
\hline SF72 & СT19 & $\mathbf{R}$ & $\mathbf{R}$ & $\mathrm{S}$ & $\operatorname{aph}\left(3^{\prime}\right)-V l a$, ant((3") $)-l a$, and $\operatorname{aac}\left(3^{\prime}\right)-l a$ \\
\hline SF73 & СТ19 & $\mathbf{R}$ & $\mathbf{R}$ & $\mathrm{S}$ & $a p h\left(3^{\prime}\right)-V l a$, ant(3")-la, and $\operatorname{aac}\left(3^{\prime}\right)-l a$ \\
\hline SF74 & СТ19 & $\mathbf{R}$ & $\mathbf{R}$ & $\mathrm{S}$ & $\operatorname{aph}\left(3^{\prime}\right)-V l a$, ant( $\left.3^{\prime \prime}\right)-l a$, and $\operatorname{aac}\left(3^{\prime}\right)-l a$ \\
\hline SF75 & ST17 & $\mathbf{R}$ & $\mathbf{R}$ & $\mathrm{S}$ & $a p h\left(3^{\prime}\right)-V l a$ and $a a c\left(3^{\prime}\right)-l a$ \\
\hline SF76 & ST18 & $\mathbf{R}$ & $\mathbf{R}$ & $\mathrm{S}$ & $a p h\left(3^{\prime}\right)-V l a$ and $a a c\left(3^{\prime}\right)-l a$ \\
\hline SF77 & ST19 & $\mathbf{R}$ & $\mathbf{R}$ & $\mathrm{S}$ & $a p h\left(3^{\prime}\right)-V l a$ and $\operatorname{aac}\left(3^{\prime}\right)-l a$ \\
\hline SF78 & ST20 & $\mathbf{R}$ & $\mathbf{R}$ & $\mathrm{S}$ & $a p h\left(3^{\prime}\right)-V l a$ and $a a c\left(3^{\prime}\right)-l a$ \\
\hline SF79 & СТ20 & $\mathbf{R}$ & $\mathrm{s}$ & $\mathbf{R}$ & ant(2")-la \\
\hline SF80 & СТ20 & $\mathbf{R}$ & $\mathrm{S}$ & $\mathrm{R}$ & $\operatorname{ant}\left(2^{\prime \prime}\right)-l a$ \\
\hline SF81 & CT21 & $\mathbf{R}$ & $\mathbf{R}$ & $\mathrm{s}$ & 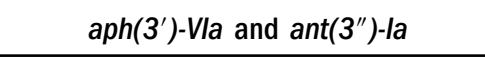 \\
\hline SF82 & CT21 & $\mathbf{R}$ & $\mathbf{R}$ & $\mathrm{S}$ & aph $\left(3^{\prime}\right)-V l a$ and ant( $\left.3^{\prime \prime}\right)-l a$ \\
\hline SF83 & ST21 & $\mathrm{R}$ & $\mathbf{R}$ & $S$ & $\operatorname{aph}\left(3^{\prime}\right)-$ Via \\
\hline SF84 & ST22 & $\mathrm{R}$ & $\mathrm{R}$ & $S$ & $\operatorname{aph}\left(3^{\prime}\right)-V i a$ \\
\hline SF85 & ST23 & $\mathbf{R}$ & $\mathbf{R}$ & $S$ & $\operatorname{aph}\left(3^{\prime}\right)-\mathrm{Vla}$ \\
\hline
\end{tabular}

Note: G: gentamicin; A: amikacin; T: tobramycin; ERIC-PCR: enterobacterial repetitive intergenic consensus-polymerase chain reaction; AME: aminoglycoside modifying enzyme; R: resistant; S: susceptible.

the modification of one special aminoglycoside agent. Hence, it is not clear which one of these genes encoding AMEs had modified the special aminoglycoside agent.

On the other hand, according to our results, the aminoglycoside-resistant genotypes were completely matched to resistant phenotypes to each one of these aminoglycoside agents in all $A$. baumannii isolates. The findings are similar to those reported by Aghazadeh et al. [22], indicating that the AMEs had the effective role in conferring resistance to aminoglycosides.

According to the results obtained from this study, the coexistence of two or more than two genes encoding AMEs was found among $64.70 \%$ of isolates, resulting in the modification of several aminoglycoside agents simultaneously. Moreover, around $50 \%$ of A. baumannii isolates harbored one of the gene profiles of $a p h\left(3^{\prime}\right)-V i a+a a c\left(3^{\prime}\right)-I a+a n t\left(3^{\prime \prime}\right)-I a+$ $a a c\left(6^{\prime}\right)-I b+a a c\left(3^{\prime}\right)-I a$ or $a p h\left(3^{\prime \prime}\right)-V I a$. In parallel with our findings, Aghazadeh et al. [22], Wang et al. [23], and Nie et al. [24] also indicated the coexistence of genes encoding AMEs in A. baumannii isolates. Moreover, Wang et al. [23] and Nie et al. [24] indicated that the gene profile of ant (2")-Ia+ $a a c\left(6^{\prime}\right)-I b+a a c(3)-I a$ and $a a c(3)-I+a a c\left(6^{\prime}\right)-I b+a n t\left(3^{\prime \prime}\right)-I+$ $\operatorname{arm} A$ was the most predominant gene profile, respectively.

In the past few decades, molecular typing methods have become the beneficial tools for characterizing taxonomic and phylogenetic properties of infectious agents in epidemiological studies [26]. ERIC-PCR is a rapid and plausible typing method for the differentiation of the genetic variations and the identification of the clonal relatedness of the bacterial isolates [27]. According to the results obtained from ERICPCR typing of A. baumannii isolates, we found that the isolates belonging to a same clone type had similar patterns 
in genes encoding AMEs and aminoglycoside resistance phenotype, indicating the clonal dissemination of genes encoding AMEs among A. baumannii isolates.

\section{CONCLUSIONS}

Our results indicated the high prevalence of resistance to aminoglycoside agents, especially gentamicin. All aminoglycoside-resistant A. baumannii isolates harbored at least one AME genes that were completely matched with resistant phenotypes to each one of these aminoglycoside agents. These findings highlight that the coexistence of genes encoding AMEs had the effective role in conferring resistance to aminoglycosides and their clonal dissemination can be a serious concern in hospital setting.

Acknowledgements: This work was a research project that has been approved in the Department of Microbiology of Ahvaz Jundishapur University of Medical Sciences, Ahvaz, Iran. The authors would like to thank the Department of Microbiology for providing the laboratory equipments.

All authors contributed to interpretation of the data, critically revised the article, and approved the final version of the manuscript.

Conflict of Interest: The authors promised there were not any possible conflicts of interest in this research.

\section{REFERENCES}

1. Alsan, M., Klompas, M.: Acinetobacter baumannii: An emerging and important pathogen. J Clin Outcomes Manag 17, 363-369 (2010).

2. Howard, A., O’Donoghue, M., Feeney, A., Sleator, R. D.: Acinetobacter baumannii: An emerging opportunistic pathogen. Virulence 3, 243-250 (2012).

3. Li, Y., Guo, Q., Wang, P., Zhu, D., Ye, X., Wu, S., Wang, M.: Clonal dissemination of extensively drug-resistant Acinetobacter baumannii producing an OXA-23 $\beta$-lactamase at a teaching hospital in Shanghai, China. J Microbiol Immunol Infect 48, 101-108 (2015).

4. Viehman, J. A., Nguyen, M. H., Doi, Y.: Treatment options for carbapenem-resistant and extensively drug-resistant Acinetobacter baumannii infections. Drugs 74, 1315-1333 (2014).

5. Yoon, E. J., Goussard, S., Touchon, M., Krizova, L., Cerqueira, G., Murphy, C., Lambert, T, Grillot-Courvalin, C., Nemec, A., Courvalin, P.: Origin in Acinetobacter guillouiae and dissemination of the aminoglycoside-modifying enzyme Aph(3')-VI. MBio 5, e01972-e0197214 (2014).

6. Garneau-Tsodikova, S., Labby, K. J.: Mechanisms of resistance to aminoglycoside antibiotics: Overview and perspectives. Medchemcomm 7, 11-27 (2016).

7. Wu, Q., Zhang, Y., Han, L., Sun, J., Ni, Y.: Plasmid-mediated $16 \mathrm{~S}$ rRNA methylases in aminoglycoside-resistant Enterobacteriaceae isolates in Shanghai, China. Antimicrob Agents Chemother 53, 271-272 (2009).
8. Gholami, M., Haghshenas, M., Moshiri, M., Razavi, S., Pournajaf, A., Irajian, G, Heidary, M.: Frequency of 16S rRNA methylase and aminoglycoside-modifying enzyme genes among clinical isolates of Acinetobacter baumannii in Iran. Iran J Pathol 12, 329-338 (2017).

9. Aliakbarzade, K., Farajnia, S., KarimiNik, A., Zarei, F., Tanomand, A.: Prevalence of aminoglycoside resistance genes in Acinetobacter baumannii isolates. Jundishapur J Microbiol 7, e11924 (2014).

10. Hasani, A., Sheikhalizadeh, V., Ahangarzadeh Rezaee, M., Rahmati-Yamchi, M., Hasani, A., Ghotaslou, R., Goli, H. R.: Frequency of aminoglycoside-modifying enzymes and ArmA among different sequence groups of Acinetobacter baumannii in Iran. Microb Drug Resist 22, 347-353 (2016).

11. Heidary, M., Salimi Chirani, A., Khoshnood, S., Eslami, G., Atyabi, S. M., Nazem, H., Fazilati, M., Hashemi, A., Soleimani, S.: Molecular detection of aminoglycoside-modifying enzyme genes in Acinetobacter baumannii clinical isolates. Acta Microbiol Immunol Hung 64, 143-150 (2017).

12. Amin, M., Navidifar, T., Shooshtari, F. S., Goodarzi, H.: Association of the genes encoding metallo- $\beta$-lactamase with the presence of integrons among multidrug-resistant clinical isolates of Acinetobacter baumannii. Infect Drug Resist 12, 1171-1180 (2019).

13. Turton, J. F., Woodford, N., Glover, J., Yarde, S., Kaufmann, M. E., Pitt, T. L.: Identification of Acinetobacter baumannii by detection of the $b l a_{\text {OXA-51-like carbapenemase gene intrinsic to }}$ this species. J Clin Microbiol 44, 2974-2976 (2006).

14. Clinical and Laboratory Standards Institute: Performance Standards for Antimicrobial Susceptibility Testing; TwentyEight Informational Supplement. M100-S28. CLSI, Wayne, PA, USA, 2018.

15. Li, P., Niu, W., Li, H., Lei, H., Liu, W., Zhao, X., Yuan, X., Liu, H., Yuan, J., Bai, C.: Rapid detection of Acinetobacter baumannii and molecular epidemiology of carbapenem-resistant A. baumannii in two comprehensive hospitals of Beijing, China. Front Microbiol 6, 997 (2015).

16. Tavakol, M., Momtaz, H., Mohajeri, P., Shokoohizadeh, L., Tajbakhsh, E.: Genotyping and distribution of putative virulence factors and antibiotic resistance genes of Acinetobacter baumannii strains isolated from raw meat. Antimicrob Resist Infect Control 7, 120 (2018).

17. Amin, M., Mehdipour, G., Navidifar, T.: High distribution of $16 \mathrm{~S}$ rRNA methylase genes $r m t B$ and armA among Enterobacter cloacae strains isolated from an Ahvaz teaching hospital, Iran. Acta Microbiol Immunol Hung 66, 337-348 (2019).

18. Manchanda, V., Sanchaita, S., Singh, N.: Multidrug resistant Acinetobacter. J Glob Infect Dis 2, 291-304 (2010).

19. Fishbain, J., Peleg, A. Y.: Treatment of Acinetobacter infections. Clin Infect Dis 51, 79-84 (2010).

20. Moniri, R., Farahani, R. K., Shajari, G., Shirazi, M. N., Ghasemi, A.: Molecular epidemiology of aminoglycosides resistance in Acinetobacter spp. with emergence of multidrug-resistant strains. Iran J Public Health 39, 63-68 (2010).

21. Upadhyay, S., Khyriem, A. B., Bhattacharya, P., Bhattacharjee, A., Joshi, S. R.: High-level aminoglycoside resistance in Acinetobacter baumannii recovered from intensive care unit 
patients in Northeastern India. Indian J Med Microbiol 36, 43-48 (2018).

22. Aghazadeh, M., Rezaee, M. A., Nahaei, M. R., Mahdian, R., Pajand, O., Saffari, F., Hassan, M., Hojabri, Z.: Dissemination of aminoglycoside-modifying enzymes and $16 \mathrm{~S}$ rRNA methylases among Acinetobacter baumannii and Pseudomonas aeruginosa isolates. Microb Drug Resist 19, 282-288 (2013).

23. Wang, Y., Shen, M., Yang, J., Dai, M., Chang, Y., Zhang, C., Luan, G., Ling, B., Jia, X.: Prevalence of carbapenemases among high-level aminoglycoside-resistant Acinetobacter baumannii isolates in a university hospital in China. Exp Ther Med 12, 3642-3652 (2016).

24. Nie, L., Lv, Y., Yuan, M., Hu, X., Nie, T., Yang, X., Li, G., Pang, J., Zhang, J., Li, C., Wang, X., You, X.: Genetic basis of high level aminoglycoside resistance in Acinetobacter baumannii from Beijing, China. Acta Pharm Sin B 4, 295-300 (2014).

25. Atasoy, A. R., Ciftci, I. H., Petek, M.: Modifying enzymes related aminoglycoside: Analyses of resistant Acinetobacter isolates. Int J Clin Exp Med 8, 2874-2880 (2015).

26. Ranjbar, R., Karami, A., Farshad, S., Giammanco, G. M., Mammina, C.: Typing methods used in the molecular epidemiology of microbial pathogens: A how-to guide. New Microbiol. 37, 1-15 (2014).

27. Kosek, M., Yori, P. P., Gilman, R. H., Vela, H., Olortegui, M. P., Chavez, C. B., Calderon, M., Bao, J. P., Hall, E., Maves, R., Burga, R., Sanchez, G. M.: Facilitated molecular typing of Shigella isolates using ERIC-PCR. Am J Trop Med Hyg 86, 1018-1025 (2012). 